\title{
Öğretmen Adaylarının “AIDS” Kavramı Konusundaki Bilişsel Yapıları: Çizme-Yazma Tekniği Örneğgi
}

\section{Student Teachers' Cognitive Structure on the Concept of "AIDS": The Drawing-Writing Technique Sample}

Gülay Ekici a,*

${ }^{\text {a} P r o f . ~ D r . G a z i ~ U ̈ n i v e r s i t e s i, ~ G a z i ~ E g ̆ i t i m ~ F a k u ̈ l t e s i, ~ E g ̆ i t i m ~ B i l i m l e r i ~ B o ̈ l u ̈ m u ̈, ~ 06500, ~ A n k a r a / T u ̈ r k i y e . ~}$

ORCID: 0000-0003-2418-1929

\section{MAKALE BİLGISİ}

\section{Makale Geçmişi:}

Başvuru tarihi: 01 Şubat 2019

Düzeltme tarihi: 25 Haziran 2019

Kabul tarihi: 17 Temmuz 2019

\section{Anahtar Kelimeler:}

Bilișsel Seviye

AIDS

Çizme Yazma Tekniği

Nitel Araştırma Modeli

\section{ARTICLE INFO}

\section{Article history:}

Received 01 Februray 2019

Received in revised form 25 June 2019

Accepted 17 July 2019

\section{Keywords:}

Cognitive Level

AIDS

Drawing-Writing Technique

Qualitative Research Model

\section{ÖZ}

$\mathrm{Bu}$ araştırmada öğretmen adaylarının AIDS kavramı konusundaki bilişsel yapıları nasıldır? sorusuna cevap aranmıştır. Çalışmada nitel araştırma modeli kapsamında durum çalışması deseni kullanılmıştır. Çalışmaya farklı branşlardan 298 öğretmen adayı katılmıştır. Veriler çizme-yazma tekniğgiyle toplanmıştır. Elde edilen verilerin analizinde içerik analizinin kullanımı tercih edilmiş olup veriler kategorilere göre yorumlanmıştır. Katılımcıların AIDS kavramı hakkındaki bilişsel yapılarının yoğunlaştığı kategorilerin "AIDS'in sonuçları, AIDS'in taşıyıcıları ve AIDS'in bulaşma yolları" kategorileri olduğu belirlenmiştir. Araştırmanın önemli sonuçlardan biri ise belirlenmiş olan tüm kategorilerde katılımcıların AIDS kavramıyla ilgili farklı kavramlara sahip oldukları ve bilişsel yapılarının yeterli düzeyde olmadığı tespit edilmiştir. Çünkü katılımcıların \%67.91'inin temsili olmayan-karikatür çizimler yaptıkları görülmüştür. Katılımcıların kategorilerde en fazla Ölüm, Mutsuz insanlar, Erkek, Kadın gibi kavramlara ait çizimler yaptıkları belirlenmiştir.

\section{A B S T R A C T}

The current study aims to determine student teachers' cognitive structures on the concept of AIDS. A case study design was applied in this qualitative research. The data were collected from 298 student teachers via drawing-writing technique. Content analysis was utilized and data were interpreted according to categories. Categorizations of student teachers' cognitive structures related to the concept of AIDS were determined to be categorized as "results of AIDS, AIDS carriers and AIDS transmission routes". One of the important results obtained was that the participants had alternative concepts related to the AIDS concept and that the cognitive structures were not in sufficient level in all the determined categories. It was seen that $67.91 \%$ of the participants did drawings without representations/cartoon drawings. It was determined that the participants did mostly draw drawings of concepts such as Death, Unhappy People, Male, and Female in different categories.

\section{Giriş}

ÇA ̆IN VEBASI AIDS!

1980’li yıllarda çağın vebası olarak adlandırılan ve dünyada pek çok ülkede insanların korkulu rüyası haline gelen hastalık AIDS’tir. Edinsel Băğşsılılı Yetmezliği Sendromu olarak bilinen AIDS (Acquired Immun Deficiencey Syndrome), bağıșıklık sisteminin zayıflamasına, görevlerini yeterince yapamaz hale gelmesine ve bunun sonucunda pek çok hastalığın ortaya çıkmasına sebep olan HIV'in sebep olduğu önemli bir hastalıktır (Krahnke,1992; Stine, 1996).
HIV ise Insan Immün Yetmezliği Virüsü olarak bilinen (Human Immuno deficiency Virus) AIDS'e neden olan birbirine benzeyen virüs grubunun adıdır (Kökdemir, 2001; Krahnke, 1992).Dolayısıyla AIDS, HIV virüsünün bağışıklık sistemini zayıf bıraktıktan sonra ortaya çıkan hastalıklar bütünüdür.

İlgili kaynaklar dünyada ilk defa AIDS ile ilgili hasta bilgilerinin 1981 yılında Amerika Birleşik devletlerinde kayıtlara girdiğini belirtmektedir. AIDS çağın vebası olarak ifade edilmekte olup yaklaşık 78 milyon insan AIDS'e yakalanmıştır. 2016 yılı kayıtlarına göre dünyada yaklaşık olarak HIV virüsü ilk ortaya çıktığı günden günümüze kadar, 35 milyon insan bu hastalık nedeniyle hayatını

*Sorumlu yazar/Corresponding author

e-posta: gulayekici@yahoo.com 
kaybetmiştir. Özellikle gelişmiş batı Avrupa ülkelerinde çok pahalı olan etkili tedaviler yapılmakla birlikte, bu tedaviler sonucunda hastalar, hastalığın belirlendiği 1980'li yıllara göre daha uzun süre yaşayabiliyor olsalar da kesinlikle tüm hastalar için sonunda ölüm kaçınılmaz olmaktadır (Artan ve Güleser, 2006; Beydağ, 2007; Green, 2007; https://indigodergisi.com/2017/11/hiv-aids-

arastirmasi). $\mathrm{Bu}$ tedavilerin sadece hastanın yaşam kalitesini arttırabildiğini söylemek mümkündür.

Yapılan araştırmalarda Birleşmiş Milletlerin çalışma programı kapsamında UNICEF' in açılamalarına göre son yıllarda yaklaşık 42 milyon insan HIV/AIDS salgınından etkilenmektedir (Green, 2007; https://indigodergisi.com/ 2017/11/hiv-aids-arastirmasi; UNIADS/ WHO, 2012). Bu kapsamda dünyadaki HIV/AIDS taşıyıcılarının yoğun olarak Afrika ülkelerinde (\%69.3'ü) yaşadığ 1 belirtilirken (Eskiocak ve Saltık, 2002), farklı kıtalardan 180'den fazla ülkenin HIV/AIDS hastalarının bilgileri artarak kayıt altına alınmaktadır (Glick, 1993; WHO, 1992). Dünya Sağlık Örgütü'nün 2016 yılına ait verilerine göre, hastaların 1,8 milyonunun yeni hastalardan oluştuğu, yeni hastaların ise yoğun olarak Avrupa ülkelerinde yaşadığı ve 2016'da 1 milyon hastanın hayatını kaybettiği belirtilmektedir.

Türk insanı ilk defa Ekim 1985'te AIDS ile tanışmıştır. Bu yılda Sağlık Bakanlığınca AIDS, bilgilerinin kaydedilmesinin zorunlu olduğu, bulaşıcı ve tehlikeli hastalık listesinde ilk sıralarda yer almıştır (Kıyan, Cengiz ve Cengiz, 1993). Türkiye'de ilk ortaya çıktığı yılda vaka sayısı 3 iken, bu sayının her yıl arttığı, 2012 yılı kayıtlarına göre yaklaşık 5225 AIDS hastası kaydı bulunduğu (http://www.AIDSbelirtileri. com/AIDS.html) ve 2016 yılında bu sayının 14 bini aştı̆̆ı, bu artışın devam ettiği düşünülecek olursa 2022 yılında belirlenen HIV/AIDS'li kişi sayısının 40 bine yaklaşacağına dikkat çekilmektedir (http://www.mavilab.com.tr/turkiyede-aids.html; https://indigodergisi.com/2017/ 11/hiv-aids-arastirmasi).

AIDS/HIV'in canlıdan canlıya bulaştığı dört farklı yol olduğu vurgulanmaktadır. Bunlar;

(1) AIDS/HIV bulaşmış kan, kan malzemeleri, doku ve organ nakli vb yollarla,

(2) Cinsel ilişsi yoluyla,

(3) Ortak kullanılan enjektör gibi sağlık ürünleri, jilet vb kesici-delici araçlar gibi kanla enfekte olmuş araçlar yoluyla ve

(4) Bebeğe annesinden bulaşabilir ki bu doğum sürecinde ve doğum sonrasında emzirmek yoluyla bulaşmaktadır (Ergör ve Serdar, 1998; Krahnke, 1992).

Bulaşma yollarından da anlaşıldığı gibi HIV virüsünün doğrudan kana geçmesi, yaşamını ve canlılığını devam ettirebilmesi için temel şarttır. Korunmanın en önemli yolunun; bu konuda eğitim almak olduğu yapılan çalışmalarda dile getirilmektedir (Esen, 1993; Pekşen ve diğerleri, 1994; Tümer ve Ünal, 2003). Ancak Türkiye'de, hastalık hakkında bilgilenme ve hastalıktan korunmaya yönelik eğitilmişlik ve bilinçlilik düzeyinin oldukça düşük olduğu belirtilmektedir. 21.347 kişinin katılımıyla yapılan araştırma sonuçlarına göre; Türkiye'de kişilerin yaklaşık \%77,3'ünün HIV/AIDS konusunda bilgisinin yetersiz olduğu ifade edilmektedir (https://indigodergisi.com/2017/ 11/hiv-aids-arastirmasi).Bu durum, 15-24 yaş grubunda yer alan genç nüfusun hastalığın en yaygın olması sebebiyle ciddi risk altında olduğuna işaret etmektedir (Kadıoğlu, 2002; Özcebe ve diğerleri, 2004; Rotheram-Borus ve diğerleri, 2000; St. Lawrence ve diğerleri, 2002). Süreçte en önemli çözümün, geleceğin öğretmenleri olacak öğretmen adaylarının nitelikli bilgilerle bilişsel yapılarını oluşturabilmekten geçtiği söylenebilir. Böylece bu öğretmen adaylarıyla gelecek nesilleri AIDS konusunda eğitebilmek ve bilinçlendirebilmek çok daha kolay olabilecektir.

AIDS hastalığının etkeni, karmaşık olan süreci, tedavisinin olmaması, sonuçları, toplumun algısı vd. açısından öğrencilerin bilişsel yapılarını oluşturmakta zorluk çektikleri konulardandır. Çünkü öğrencilerin hastalıkları ve hastalıklara sebep olan canlıları (bakteri, virüs vd.) somut olarak algılayamadıkları ve öğrenmekte zorluk çektikleri bilinmektedir (Byrne, 2011; Ergazaki ve diğerleri, 2010; Uzunkaya ve Özgür, 2011). Bilişsel yapının nasıl oluşturulduğu konusunda ilgili alan yazında görüş birliği sağlanamamış olmakla birlikte (Chi ve diğerleri, 1994; Franco ve diğerleri, 1999; Vosniadou ve Brewer, 1994a; Vosniadou ve Brewer, 1994b), bireylerin kavramlar hakkında düşünceleri belirlenerek konuyla ilgili detaylı veriler elde edilebileceği ifade edilmektedir (Gilbert ve diğerleri, 1998a; Gilbert ve diğerleri, 1998b). Çünkü kavramlar konusunda ortaya konulmuş araştırmalar katılımcıların araştırılan kavramın bireylerin zihninde var olan bilişsel yapılarını belirlemekte etkili olabileceği belirtilmektedir.

Kavramsal öğrenmeyi belirleyen ve ilgili alanyazında tamamlayıcı ölçme-değerlendirme teknikleri olarak ifade edilen ölçme araçlarıyla, katılımcıların kavramlarla ilgili sahip oldukları bilgilerinin yanında; kavramlar arasındaki ilişkisel bağı, bilişsel yapılarını, zihinlerinde önceden öğrendikleri bilgilerle yeni öğrendikleri bilgileri ilişkilendirip anlamlı öğrenme gerçekleştiripgerçekleştiremedikleri ve zihinlerinde oluşturdukları bilgilere ait şemalarla günlük yaşamlarındaki olayların süreci arasındaki benzerlikleri ne kadar anlayabildiklerini (Backett-Milburn ve Mckie, 1999; Patrick ve Tunnicliffe, 2010; Garland, 2005) ve sahip oldukları alternatif kavramlarını analiz etmekte kullanabildikleri vurgulanmaktadır. Çizim-yazım tekniği bu tekniklerden biridir. Bu tekniğin basit ama uluslararası ve disiplinler arası geçerliliği olan nitelikli veriler sağladığı vurgulanmaktadır (Ainsworth, Prain ve Tytler, 2011; Bartoszeck, Machado ve Amann-Gainotti, 2008; Borthwick, 2011; Christensen ve James, 2000; Rennie ve Jarvis, 1995). Bu teknik katılımcıların analiz edilmek istenilen kavramlar konusunda hem bilinmesi gerektiği vurgulanarak kabul gören akademik bilişsel yapıların ortaya çıkartılmasında hem de bilmesinin onaylanmadığı bilimdışı bilişsel yapılarının ortaya çıkartılmasında tercih edildiği vurgulanmaktadır. Bilimsel anlamda doğru olmayan ve bilimsel gerçeklerle uyumlu olmayan bu kavramsal yapılarla ilgili alanyazında farklılık gösteren açıklamalar dikkat çekmektedir. Bu araştırmada ilgili alanyazında ifade edilen "alternatif kavramlar" (Doran, 1972; Driver, 1989; Driver ve Easley, 1978; Gonzalez, 1997; Mike ve Treagust, 1998; Smith, Blakeslee ve Anderson, 1993) ifadesinin kullanımı tercih edilmiştir.

Alanyazında farklı grupların AIDS konusundaki bilgi düzeylerinin belirlendiği araştırmalara rastlanmaktadır 
(Brotman, Mensah ve Lesko, 2010; Çekin ve diğerleri, 2013; Ekin, 2014; Gan'Czak ve diğerleri, 2007; Kaya, Akıllı ve Sezek, 2010; Köse ve diğerleri, 2012; Mutonyi, Nashon ve Nielsen, 2010). Bu araştırmalarda açık uçlu soru formu (Korkmaz, 2001), anket (Ekin, 2014; İnci, 2014; Kurt veYılmaz, 2012; Nwokocha ve Nwakoby, 2002) ve farklı görüşme türleri (Gao ve diğerleri, 2012; Mutonyi, Nashon ve Nielsen, 2010; Özdemir ve diğerleri, 2006) gibi veri toplama araçları çeşitlerinin kullanımının tercih edildiği belirlenmiştir. Bu kapsamda alanyazında öğretmen adaylarının katılımcı olarak tercih edilerek hazırlanmıș olan araştırmaların sayıca yeterli olmadığı bilgisine ulaşılmıştır (İçli veYalçın, 2002; Korkmaz, 2001). Ayrıca alanyazında çizim tekniğiyle González-Rivera (2007) yaptığı çalışmada 10 yaş grubu çocukların AIDS'li hastalara yönelik tutumlarını belirlemiştir. İlgili alanyazından elde edilen sonuçlar, AIDS kavramıyla ilgili olarak öğretmen adaylarının bilişsel yapılarının çizme-yazma tekniği kullanılarak yapıldığı bir araştırmanın olmadığını göstermiştir. Bu araştırmanın; yöntemi ve deseni açısından, katılımcıları açısından, kullanılan veri toplama araçları açısından, verilerin analizi açısından ve elde edilen sonuçlar açısından, konuyla ilgili alanyazında yeni araştırmalara 1 şık tutacak şekilde nitelikli veriler kazandıracağı düşünülmektedir. Ayrıca gelecek nesillerin eğitimlerinde önemli görevler üstlenecek olan öğretmen adaylarıyla yapılmış olması çalışmaya çok daha anlam katmaktadır.

\subsection{Araştırmanın Amacı}

$\mathrm{Bu}$ araştırmada öğretmen adaylarının AIDS kavramı konusundaki bilişsel yapıları nasıldır? sorusuna cevap aranmış ve araştırma bu amaç doğrultusunda düzenlenmiştir.

\section{Yöntem}

\subsection{Araştırma Modeli}

$\mathrm{Bu}$ çalışmada nitel araştırma modelinin kullanımının uygun olduğu belirlenmiştir. Çünkü nitel araştırma modelinin kullanıldığı araştırmalarda gözlem, görüşme, doküman vb gibi veri elde etme yöntemlerinden yararlanılarak, analiz edilen kavramlar, olgular, ilişkiler açıklanmaya çalışılarak (Merriam, 1998) konuyla ilgili detaylı veri toplanabilmektedir. Nitel araştırmanın bilim insanları tarafından ortak açıklamalar yapılarak herkes tarafından kabul edilebilen bir tanımının belirtilmesinin oldukça zor olduğunu belirtmek gerekir. Bunun temel nedeni ise, nitel araştırma yönteminin şemsiye bir kavram olarak ele alınmasıdır. Nitel araştırma yönteminin içerisinde bu şemsiye altında yer alabilecek birçok kavramın farklı disiplinlerle yakından ilişkili olmasıdır.Diğer taraftan nitel araştırma modeli kapsamında birçok desen kullanılmakta olup bu araştırmada durum çalışması deseni kullanılmıştır. Durum çalışması sosyal bilimlerdeki araştırmalarda kullanılan önemli desenlerinden biridir. Açıklayıcı durum çalışmaları (explanatory case study), keşfedici (exploratory) ve tanımlayıcı durum çalışmaları (Yin, 2003:1) olmak üzere üç çeşidi vardır. Bu araştırmada açıklayıcı durum çalışması deseninin kullanımı tercih edilmiş olup öğretmen adaylarının AIDS" kavramı konusundaki bilişsel yapılarının analiz edilmesi amaçlanmıştır. Genelde yapılması zor olan deneysel desendeki araştırmalarla analiz edilmesi mümkün olmayan ve çok karmaşık olan araştırmalarda bu araştırma deseninin kullanımı tercih edilmektedir. Durum çalışması, bir olgunun yer aldığı doğal yaşam çerçevesi kapsamında belirlenmesini, durumları çok boyutlu, sistematik ve detaylarıyla incelenmesini amaçlayan bir araştırma desenidir (Cohen ve Manion, 1997;Hitchock ve Hughes, 1995; McMillan, 2000; Verma ve Mallick, 1999; Yıldırım ve Şimşek, 2016). Durum çalışmasında verilerin mümkün olduğunca detaylı, ilk ağızdan alıntılarla ve katılımcıların vurguladıkları cümleleriyle açıklanması oldukça önemlidir (Patton, 1990; Punch, 2005). Ayrıca durum çalışması küçük örnek bir durumu açıklamayı amaçladığından genele vurgu yapmaktan çok ilgili durumdan en nitelikli şekilde hangi sonuçların elde edildiğinin vurgusu konusunda hazırlanmaktadır (Denzin ve Lincoln, 1985:435). Bu çalışmada da veriler mümkün olduğunca detaylı analiz edilmiş, uygun bölümlerde hem çizimlerden hem de yazımlardan örnekler verilmiştir.

\section{2. Çalışma Grubu}

Araştırma Gazi Üniversitesi Gazi Eğitim Fakültesinin farklı bölümlerinde eğitim görmekte olan toplam 298 öğretmen adayının katılımıyla hazırlanmıştır. $\mathrm{Bu}$ kapsamda araştırmada amaçlı örneklem türlerinden maksimum çeşitlilik örneklemesi yapılmıştır. $\mathrm{Bu}$ örneklem türünde evrenin içinde var olan tüm farklı durumları yansıtacak katılımcılar tüm çalışma örneklemlerinden çalışmaya dahil edilirler. Çünkü Luborsky ve Rubinstein (1995), çalışma grubunun (çalışma örnekleminin) seçiminde, katılımcıların nitel çalışmalarda nitelikli verilerin elde edilebilmesi için araştırma konusundaki amaç ve hedeflerle ilgili ne kadar detaylı görüş bildirebileceklerine göre ve çalışma grubundaki katılımcıların çalışmaya uygunluğu açısından değerlendirilmesi gerektiği vurgusu yapmaktadırlar.

Öğretmen adaylarının seçiminde çalışmaya katılmasında bir sakıncanın olmaması, çalışmaya katılmak istemesi, araştırmacının katılımı ırubuna ulaşmasında zorlukların en aza indirgenebilmiş olması, maksimum çeşitlilik örneklemesi yönünde sosyal ve fen alanlarından farklı öğretmenlik branşlarında eğitimlerine devam eden öğretmen adaylarının katılımın sağlanması gibi ölçütler dikkate alınmıştır. Bu kapsamda amaçlı çalışma grubu seçiminde araştırmacının veri toplamakta karşılaşabileceği problemler (Given, 2008; Knight ve diğerleri, 2013) giderilmeye çalışılmıştır. Öğretmen adaylarının \%68.58'i $(n=203)$ k1z ve \%31.42'i (n=93) erkektir. Diğer taraftan öğretmen adaylarının \%59.40’1 $(n=177)$ sosyal bölümlerde eğitimlerine devam ederlerken $[\% 32.20$ 'i Sinıf ögretmenliği, \%28.25 'i Okul Öncesi ögretmenliği, \%22.60’ Sosyal Bilgiler ögretmenliği ve \%16.95'i Tarih ögretmenliği], \%40.60'1 $(\mathrm{n}=121) \quad$ fen bölümlerinde eğitimlerine devam etmektedirler [\%16.53'ü Fen Bilgisi ögretmenliği, \%32.23'ü Biyoloji ögretmenliği, \%31.41'i Fizik ögretmenliği ve \%30.58'i Kimya öğretmenliği].

\subsection{Veri Toplama Arac1}

Bogdan ve Biklen (2007)'e göre durum çalışmalarında dokümanlar çok önemli veri kaynaklarıdır. Bu çalışmada da katılımcılara ait veriler elde edebilmek amacıyla öğretmen adaylarının kendi el yazılarıyla cevap kâğıtları (dokümanlar) hazırlatılmıştır. Araştırma verileri çizmeyazma tekniğiyle toplanmıştır ki çizme-yazma tekniğinin hem ulusal hem de uluslararasında birçok araştırmada 
kullanımının tercih edildiği belirlenmiștir (Cetin ve diğerleri, 2013; Kalvaitis ve Monhardt, 2012; Nyachwayaa ve diğerleri, 2011;Shepardson ve diğerleri, 2007). Çizmeyazma tekniği öğrenenlerin zihninde kavramlarla ilgili kullanılmayarak pasif konumda olan düşünce, anlam, tutum, imaj ve bilişsel yapılarla ilgili görselleri aktif hale getirmeyi amaçlaması, bunları zihinsel depoda yer alan kişiye özel ve bilimsel değeri yüksek veriler şeklinde elde edilmesini sağlaması açısından yeterince faydalıdır. Çalışmada öğretmen adaylarının toplam 5 dakikalık bir sürede "AIDS/HIV kavramlarlyla ilişkili bilgilerinizi şekille çizerek anlatınız?" sorusuna görüşlerini çekinmeden ve kapsamlı şekilde ifade etmeleri istenmiş olup verilerin katılımcılara ait hiçbir bilgiye yer verilmeden akademik bir yayında kullanılacağı açıklanmıştır. Şekil A ve Şekil B'de çizme-yazma tekniğine ait öğretmen adaylarının çizimlerinden örnekler aktarılmıştır.

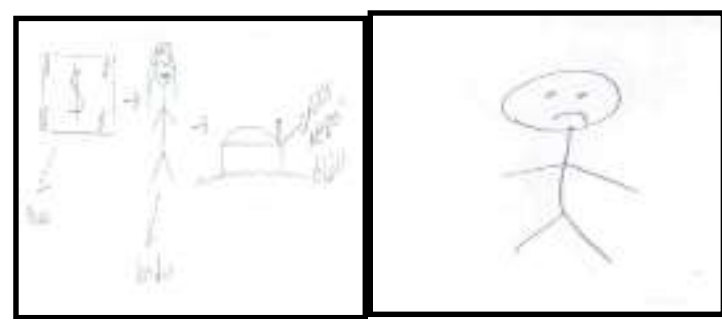

Şekil A. K23'e Ait Çizim Örneği

\subsection{Verilerin Analizi}

Öğretmen adaylarının cevap kağıtlarının veri analizi sürecine dahil edilebilmesi için öncelikle tek tek 1'den 298'e kadar numara verilmiştir. $\mathrm{Bu}$ çalışmada nitel araştırma modeline göre hazırlanan araștırma verilerinin analizinde en çok kullanılan analiz türlerinden biri olan içerik analizi yöntemi tercih edilmiştir. İçerik analizinde odaklanılan nokta, elde edilen verileri nitelikli bir şekilde ifade edebilecek anlamlı kavramsal birimlere ve bilimsel bağlantılara göre düzenlemeler yapmaktır. Birlikte anlamlı bütünlerin parçalarını oluşturan veriler belirli kavramlar, alt kategoriler, kategoriler, alt temalar ve temalar çerçevesinde bir araya getirilerek ilgili verilerden yararlanmak isteyenlerin bilimsel anlamlar yükleyebilecekleri şekilde organize edilerek analiz işlemleri yapılır (Bilgin, 2006; Lichtman, 2010; Lin, Lin ve Tsai, 2014; Stemler, 2001; Wimmer ve Dominick, 2000). Nitel araştırma modelinde farklı ölçme araçlarıyla elde edilen sözel, yazılı, görsel vd. materyallerin içerik analizine göre değerlendirme işlemi verilerin nesnel ve sistematik bir şekilde incelenmesi ve belli kategorilere göre düzenlenmesini sağlayan bilimsel bir veri analizi yaklaşımıdır (Bogdan ve Biklen, 2007; Cohen, Manion ve Morrison, 2007; Hill, Thompson ve Williams, 1997; Leblebici ve Kılıç, 2004). Bu çalışmada ise, katılımcıların, çizim-yazım tekniğini kullanarak AIDS kavramıyla ilgili cevap kâğıtları içerik analizi yöntemine göre anlamsal bir bütünlük oluşturur şekilde birbirine benzeyen verileri oluşturan kodlar belirli temalar, alt temalar, kategoriler ve alt kategori kapsamında bir bütün oluşturacak şekilde analiz edilmiştir.

Elde edilen verilerin analiz süreci toplam on bir aşamada yapılmıştır. Bu aşamalar şu şekilde sıralanabilir;
(1) cevap kâğıtlarının fiziki ve içeriksel olarak incelenme aşaması,

(2) kurallara uygun olarak hazırlanmamış olan kâğıtların değerlendirme dışında bırakılması aşaması,

(3) kurallara uygun olarak hazırlanmış olan kâğıtların tekrar incelemesi aşaması,

(4) veri analizine dahil edilecek olan kağıtların 1'den 298 'e kadar numaralandırılması aşaması,

(5) cevap kâğıtlarında yer alan çizim-yazımların detaylıca incelenmesi aşaması,

(6) kodlara uygun olarak kategori geliştirme aşaması,

(7) çizim-yazımların kategori ve alt kategorilere dağılımının kararlaştırılması aşaması,

(8) geçerlik ve güvenirlik işlemlerinin yapılması aşaması,

(9) elde edilen çizim- yazımların betimsel tekrarlanma sıklık değerlerinin hesaplanması aşaması,

(10) verilerin betimsel tekrarlanma s1klık değerlerinin ne anlama geldiği yönünde değerlendirme aşaması ve

(11) NVivo9.3 programıly bilişsel modelin oluşturulma aşamasıdır.

Çizme-yazma tekniğine yapılan eleştirilerden biri, katılımcıların çizim yeteneğinin değerlendirilmesi olmamakla birlikte (Reiss ve diğerleri, 2002), asıl yapılan işlem katılımcıların çizimlerinden ilgili kavram hakkındaki bilişsel düzeylerinin belirlenmesidir. $\mathrm{Bu}$ çalışmada da öğretmen adaylarının çizimlerinin değerlendirilmesinin ötesinde çizimlerinin değerlendirilmesiyle AIDS kavramıyla ilgili bilişsel düzeylerinin belirlenmesi amaçlanmıştır. Bu noktada AIDS kavramıyla ilgili yaptıkları çizimleri bilişsel seviyelere göre analiz edilmiştir. Bilişsel seviyeler alanyazında yer alan çalışmalardan oluşturulan bilişsel seviye tespit tablosuyla yapılmış olup bu seviyeler seviye 1'den seviye 5'e kadar gruplandırılmaktadır (Bartoszeck, Machado ve AmannGainotti, 2008; Cinici, 2013; Reiss ve Tunnicliffe, 2001) (Tablo 1).

Çizme-yazma tekniğinde AIDS'le ilgili çizimlere örnekler katılımcı numaralarının K16 ve ya K27 şeklinde ilgili kategorilerde belirtilmesiyle sunulmuştur.

Tablo 1. Öğretmen adaylarının AIDS kavramı konusundaki çizimlerinin değerlendirildiği bilişsel seviye grupları

\begin{tabular}{ll}
\hline Seviyeler & \multicolumn{1}{c}{ Çizim } \\
\hline Seviye 1 & Çizimi olmayanlar \\
Seviye 2 & Temsili olmayan-karikatür çizimler \\
Seviye 3 & Alternatif kavramlar içeren çizimler \\
Seviye 4 & Kismen doğru çizimler \\
Seviye 5 & Kavramsal temsili-kapsaml çizimler \\
\hline
\end{tabular}

\subsection{Geçerlik ve Güvenirlik Çalışması}

Araştırmanın geçerliğini arttırabilmek yönünde yapılmış olan işlemler aşağıda belirtilmiştir;

(1) Araştırmanın verilerinin analizi işlemlerinin nasıl yapıldığı basamak basamak verilerin analizi başlığı altında verilmiştir (Hruschka ve diğerleri, 2004; Daymon ve Holloway, 2003), 
(2) Araştırmada verilerin analizi sonunda ulaşılan kategorik aşamaların her birine öğretmen adaylarının görüşlerinden örneklerle açıklamalar yapılmıştır (Roberts ve Priest, 2006; Wiersma ve Jurs, 2005) ve

(3) Bulgular ve yorumlar ve sonuçlar ve tartışma başlıkları altında konuyla ilgili alanyazında yer alan araştırma sonuçları detaylı olarak tartışılmış ve değerlendirmeler yapılmıştır (Ratcliff, 1995).

Diğer taraftan araștırmanın güvenirlik sürecini belirleyebilmek amacıyla katılımcı çeşitlemesine gidilmiş olmasının yanı sira uzmanlar arası uyum katsayısı hesaplanmıştır. $\mathrm{Bu}$ kapsamda kodların ilgili kavramsal kategorilerde yer alıp almadığını doğrulamak amacıyla iki alan uzmanının kodları ve kodların yer aldı $\breve{g}_{1}$ kategorileri karşılaştırılmıştır. Miles ve Huberman (1994) tarafından açıklanmış olan uzman kodlayıcılar arasındaki ortalama güvenirlik katsayısı nitel araştırmalarda sik sık kullanılmaktadır. Süreçte şu işlemler yapılmaktadır; uzmanların birbirinden bağımsız olarak belirledikleri kodların tutarlılığı "Görüş birliği" ile ifade edilirken kodların tutarsızlığı ise "Görüş ayrılığı" olarak belirlenmektedir. Uzmanların, öğretmen adaylarının çizim- yazımları için aynı kodu kullandıkları durumlar görüş birliği, farklı kodu kullandıkları durumlar ise görüş ayrılığı olarak değerlendirmeye yansitılmıştır. Bu işlemler sonunda elde edilen frekans değerleriyle hesaplanan veri analizinin güvenirlik oran1; [Görüş birliği / (Görüş birliği + Görüş ayrılığı) $x$ 100] formülüyle belirlenmiştir (Miles ve Huberman, 1994). Uzman kodlayıcılar arasındaki ortalama güvenirlik değeri \% 90 olarak hesaplanmıştır. Araştırmanın son aşamasında AIDS'le ilgili öğretmen adaylarının bilişsel yapılarına ait bilişsel modelin oluşturulmasında NVivo9.3 programı kullanılmıştır.

\section{Bulgular ve Yorumlar}

$\mathrm{Bu}$ bölümde bulgular çizme-yazma tekniğiyle elde edilen verilerin analizi, çizimlerin düzenlenerek bilişsel seviyelere göre analizi, öğretmen adaylarının AIDS kavramıyla ilgili açıklamalarının verilmesi, belirlenen alternatif kavramlarla ilgili ifadelerin açıklanması ve bölümün sonunda AIDS kavramıyla ilgili elde edilen bilişsel yapı modelinin verilmesiyle tamamlanmıştır.

Tablo 2. AIDS Kavramı Konusunda Çizme-Yazma Tekniğiyle Elde Edilen Kategori ve Alt Kategorilere Ait Bulgular

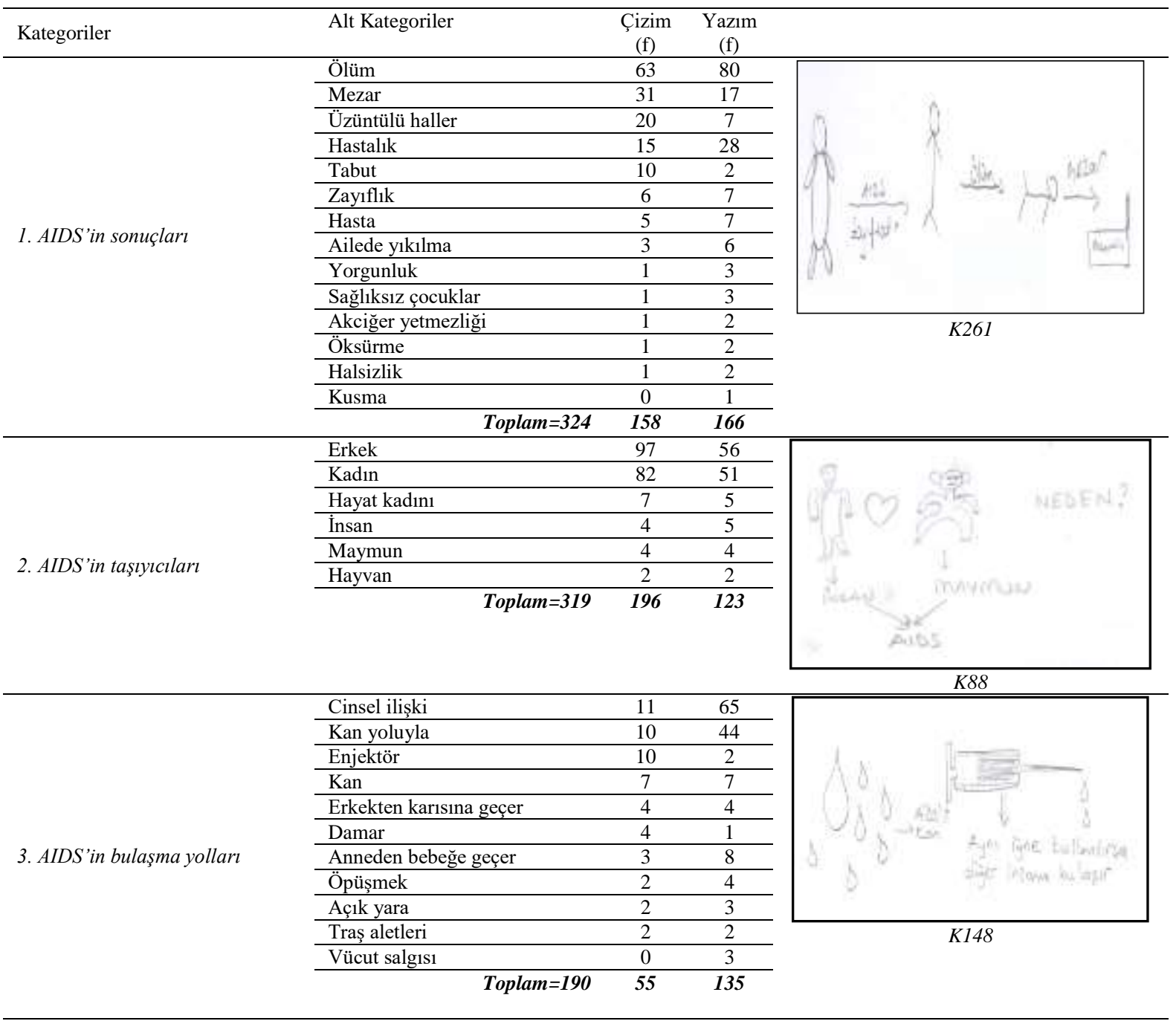




\begin{tabular}{|c|c|c|}
\hline Virüs & 26 & 41 \\
\hline Hücre & 17 & 5 \\
\hline Bağışıklık sistemi çökmesi & 5 & 13 \\
\hline HiV & 12 & 7 \\
\hline Mikrop & 11 & 4 \\
\hline HíV virüsü & 5 & 3 \\
\hline Bakteri & 2 & 1 \\
\hline Hücrenin yapısını bozan virüs & 1 & 1 \\
\hline Edinilmiş bağışıklık sendromu & 0 & 1 \\
\hline Toplam $=155$ & 80 & 75 \\
\hline Bulaşıcı & 17 & 43 \\
\hline Tehlikeli & 6 & 10 \\
\hline Öldürücü & 3 & 6 \\
\hline Çoğunlukla kadınlarda görülür & 3 & 3 \\
\hline Kalitsal & 0 & 3 \\
\hline Cevresel & 0 & 3 \\
\hline
\end{tabular}

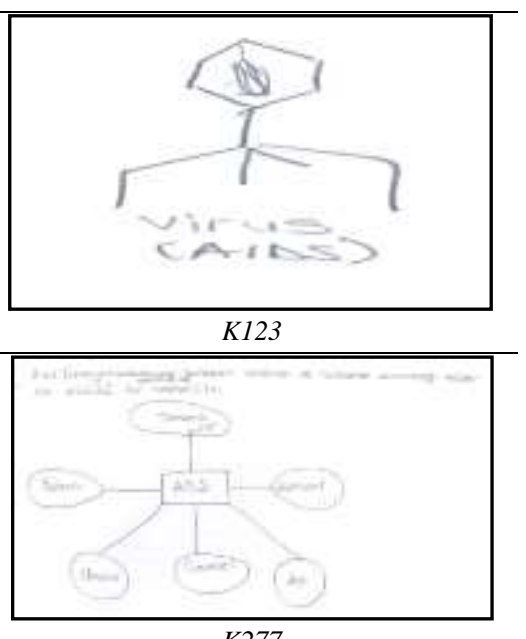

5. AIDS'in özellikleri

Toplam $=94$

K277

\begin{tabular}{|c|c|c|}
\hline Hastane & 18 & 3 \\
\hline İlaç & 5 & 5 \\
\hline Hapla yaşam uzatılıyor & 4 & 6 \\
\hline Tedavi edilemez & 2 & 21 \\
\hline Tedavi & 2 & 9 \\
\hline Doktor & 2 & 3 \\
\hline Tedavi edilebilir & 0 & 3 \\
\hline Hemşire & 2 & 2 \\
\hline Pahalı & 2 & 2 \\
\hline Toplam $=91$ & 37 & 54 \\
\hline
\end{tabular}

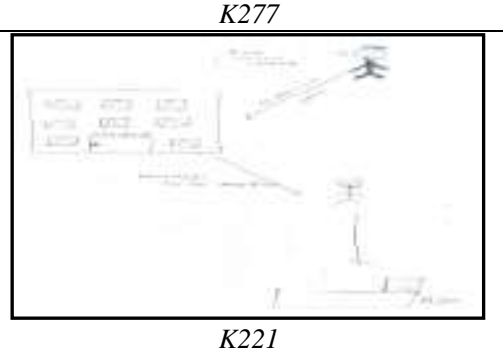

Korunmasız cinsel ilișki

Çok ilişkililik

Para

Alkol

Dikkatsizlik

7. AIDS' in bulaşma nedenler

Bilgisizlik

Sefalet

Para karşı1lığ ilişki

Eğitimsizlik

Yoksulluk

\begin{tabular}{|c|c|c|c|}
\hline & Toplam $=89$ & 23 & 66 \\
\hline Sevgi & & 53 & 0 \\
\hline
\end{tabular}

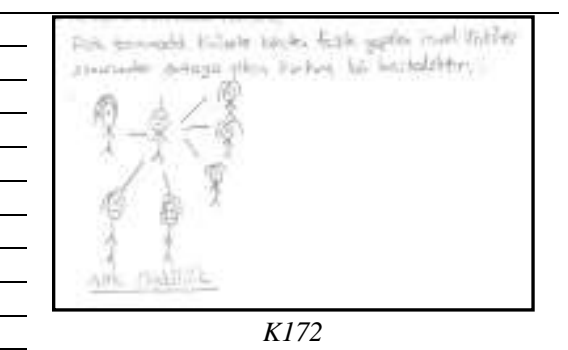

Korunma

Kondom (=prezervatif) $\quad 4 \quad 5$

Dikkat

Evlilik

Bilinç

37

$7 \quad 20$

8. AIDS'ten korunma yollart

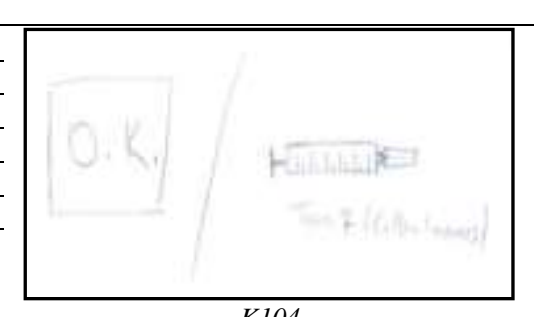

\begin{tabular}{lcc} 
Ölüme götürür & 19 & 24 \\
\hline Hastalığın ilerlemesiyle vücutta & 6 & 6
\end{tabular}

yaraların oluşması

Zorlu süreç

9. AIDS'in hastalı sürecinin

Yaşam zorluğu

Hayatı zorlar

\begin{tabular}{ccc} 
& 2 & 5 \\
\hline & 0 & 4 \\
\hline Toplam $=70$ & 0 & 4 \\
\hline 27 & $\mathbf{4 3}$
\end{tabular}

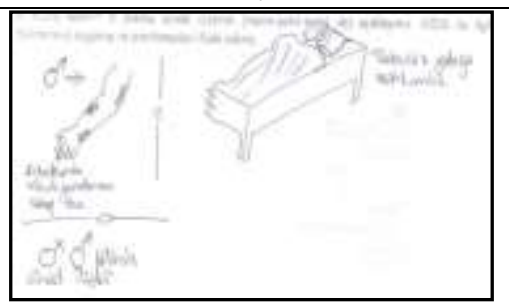

K107

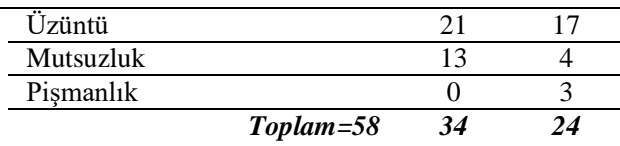

10. AIDS'li hastanın algılart

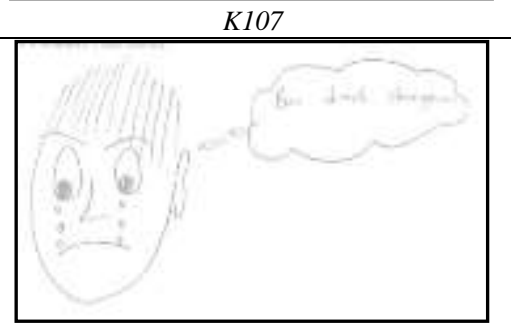

$K 150$

11. AIDS'li hastaya bakış açısı

\begin{tabular}{lll} 
Toplumdan dişlanma & 7 & 9 \\
\hline Toplumdan uzaklaşma & 6 & 8 \\
\hline Psikolojinin bozulması & 2 & 7 \\
\hline Ölüm saçan & 1 & 3 \\
\hline Antisosyal & 1 & 1 \\
\hline Olumsuz tepki & 0 & 2
\end{tabular}

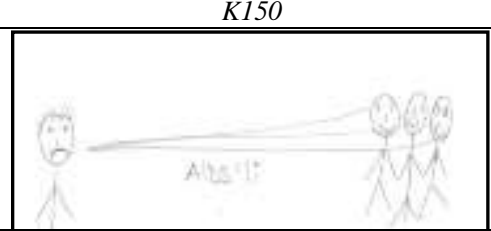




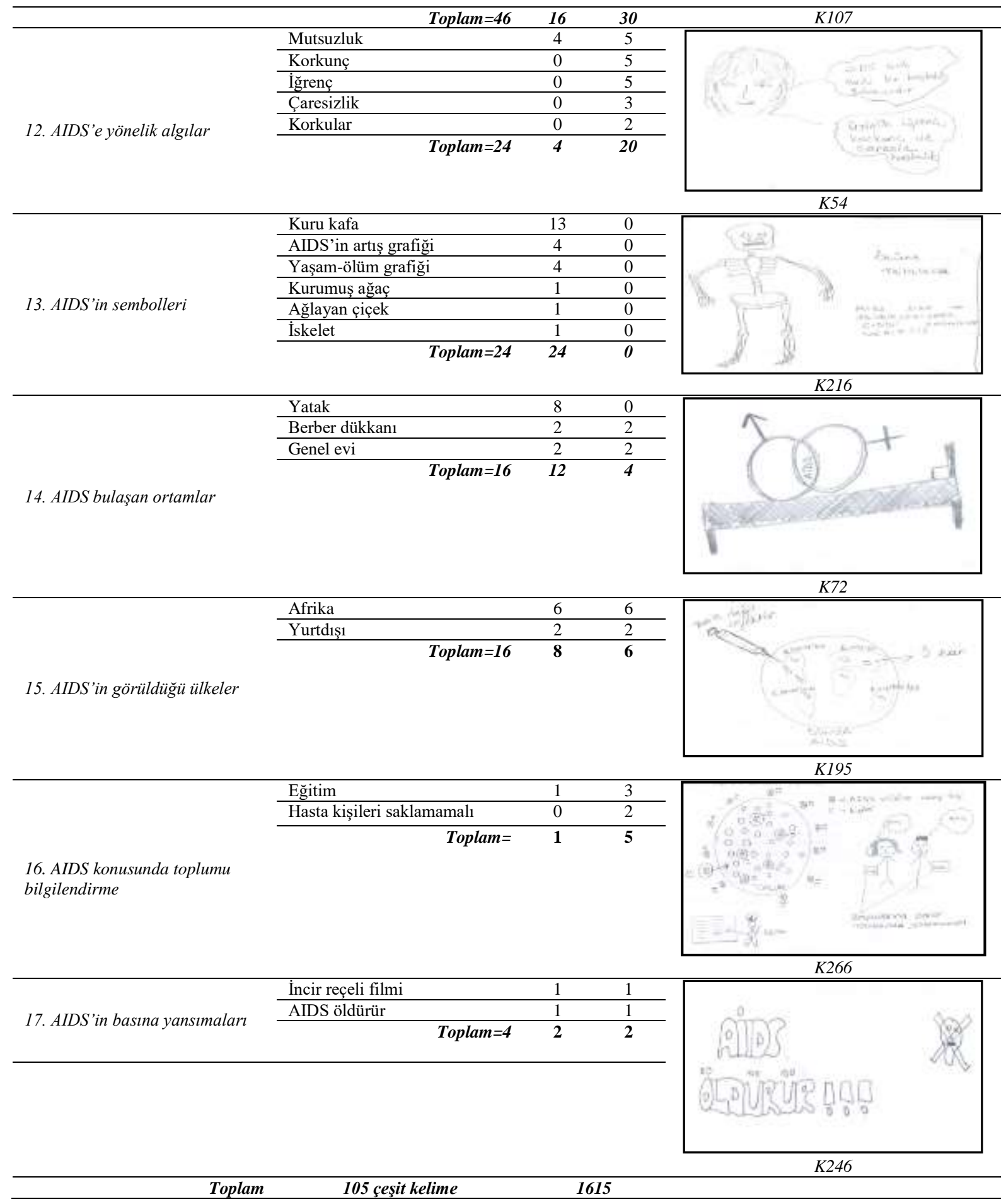

Tablo 2'de görüldüğü gibi, AIDS kavramına ait çizimyazım tekniğiyle toplamda 17 kategori belirlenmiş olup verilerin çizim tekniğiyle 17 kategori kapsamında dağılım gösterdiği ve yazım tekniğiyle 16 kategori kapsamında dağılım gösterdiği belirlenmiştir. Bu noktada yazım tekniği kapsamında "AIDS'in sembolleri" kategorisinde herhangi bir bulguya rastlanmamıştır. Öğretmen adaylarının zihinlerinde var olan AIDS kavramıyla ilgili bilişsel yapılarının hem çizme hem de yazma tekniğiyle "AIDS'in sonuçlarl" kategorisinde en yüksek değerlerde olduğu ortaya çıkmıştır. Bu kategoride en fazla Ölüm, Mezar, Üzüntülü haller, Hastalık ve Tabut kavramlarının ifade edildiği görülmektedir. Öğretmen adaylarının çizimlerinde AIDS'e ait somut kavramlarla ve AIDS'in sonuçlarından hareketle bilişsel yapılarını oluşturdukları belirlenmiştir.
Tüm kategorilerde en fazla çizilen ve yazılan kavramlar Erkek $(f=97)$ ve Kadın $(f=82)$ figürleri olmuştur.

Öğretmen adaylarının AIDS kavramıyla ilgili çizimlerine ait analizler belirlenmiş olan ilgili bilişsel seviyeler kapsamında Tablo 3'de analiz edilmiştir. Tablo 3'e göre, AIDS kavramı konusunda öğretmen adaylarının çizim tekniğiyle ifade ettikleri çizimleri en düşükten en yükseğe doğru sıralanan 5 farklı bilişsel seviye kapsamında analiz edilmiştir (Bartoszeck ve diğerleri, 2008; Cinici, 2013; Reiss ve Tunnicliffe, 2001). AIDS kavramiyla ilgili belirlenmiş olan çizimlerin temsili olmayan-karikatür çizimler (201-\%67.91), alternatif kavramlar içeren çizimler (19-\%6.42), kısmen doğru çizimler (6-\%2.03) ve kavramsal temsili-kapsaml çizimler (15-\%5.07) olarak bilişsel seviyelerde yer aldığ belirlenirken, 65 (\%21.96) öğretmen 
adayının görüşlerini açıklamakta çizim tekniğini kullanmadıkları görülmüştür. Bulgularla belirlenmiş olan bilişsel seviyeler katılımcıların yaklaşık 3/4'lük bir oranının AIDS kavramıyla ilgili bilişsel yapılarını temsili olmayankarikatür çizimlerle açıklamaya çalıştıklarını göstermektedir. Elde edilen çizimlerde öğretmen adaylarının AIDS'i daha çok kendilerince oluşturdukları kavramlarla ve temsili olmayan-karikatür çizimlerle ifade ettikleri belirlenmiştir. Bulgular öğretmen adaylarının AIDS kavramıyla ilgili detaylı bilimsel boyutları yeterince düşünüp ifade edemeden (veya bilmediklerinden) genelde yüzeysel, yeterince anlaşılamadığının vurgularını içerir şekilde, bilimsel olarak açıklanmış olan gerçekle çok fazla ilgisi kurulamamış, AIDS kavramını karikatürize ettikleri çizimlerle ve kişisel olarak günlük konuşma dilinde somutlaștırabildikleri boyutlarına ait çizimlerle açıkladıklarını yansıtmaktadır. Dolayısıyla bu çizimler öğretmen adaylarının AIDS'le ilgili bilişsel yapılarının yetersiz, hatalı ve alternatif kavramlarla kişiselleştirebildikleri çizimlerle ortaya koydukları bilişsel yapılarının akademik olarak yetersizliğinin göstergesi olarak belirlenmiştir. Belirlenen çizimlerin AIDS'in sonuçları kategorisinde Ölüm kavramına (63 çizim), AIDS'in taşı1yıları kategorisinde Erkek (97 çizim) ve Kadın (82 çizim) kavramlarına ait çizimlerde yoğunlaştıkları belirlenmiştir. Diğer taraftan kısmen doğru çizimlerinin ve kavramsal temsili-kapsamlı çizimlerin yeterli sayıda olmadığı görülmektedir.

Tablo 3.AIDS Kavramıyla İlgili Çizim-Yazım Tekniğiyle Elde Edilen Bulguların Bilişsel Seviyelere Göre Analizi

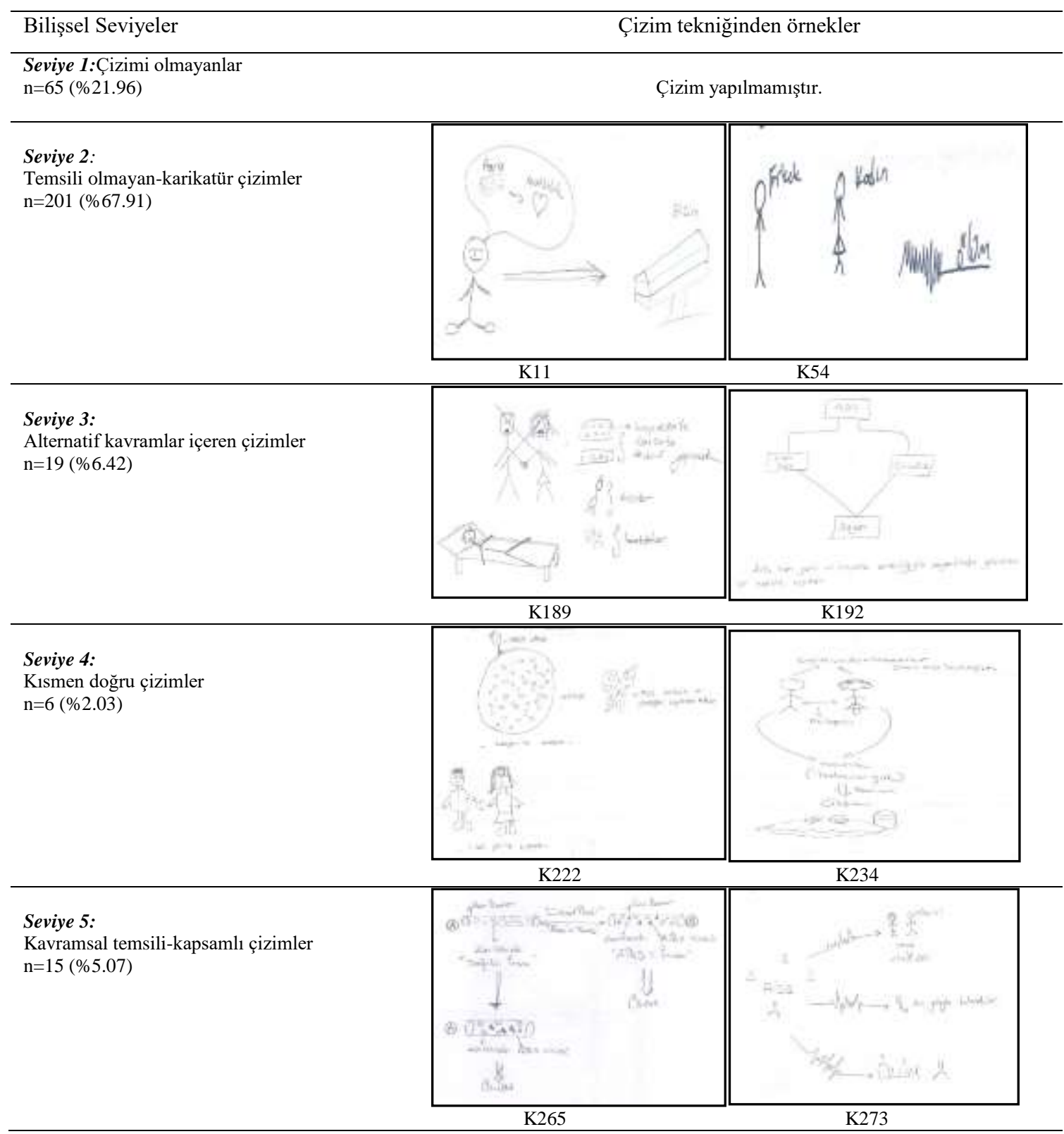

Genel olarak elde edilen bulgularda öğretmen adaylarının AIDS kavramı konusunda belirttikleri cümlelerinde pek çok alternatif kavramlarının olduğu ve ilgili kategorilerde belirttikleri cümlelerinin genelde günlük konuşma diliyle ifade edilen, yeterli bilimsel vurgusu olmayan daha çok duygusal etkilenmeyi vurgulayan ifadeler olduğu belirlenmiştir. Belirlenmiş olan alternatif kavramların ise genelde AIDS'i tanımlamaya, AIDS'e ve AIDS'li hastaya bakış açılarını, AIDS'in taşıyıcılarını açıklamaya, AIDS'in bulaşma yollarını açıklamaya, AIDS'in sonuçlarını 
açıklamaya, AIDS'in hastalık sürecini açıklamaya, AIDS'e yönelik algılarını açıklamaya vb yönelik ifadeler olduğu tespit edilmiştir. Öğretmen adaylarının belirtmiş olduğu cümlelerden alternatif kavramlar içeren cümlelere ait örneklere aşağıda yer verilmiştir;

"Virüs bir AIDS mikrobudur” (K12);"AIDS hastalı̆̆ bağışıklık sistemini çökertir ve hastayı yatalak edip vücudunda yaralar çıkar” (K24); "AIDS hastalı̆̆ genelde bayanlarda olur" (K42); "AIDS olan insanlar kuru bir ăgaç gibidirler. Hayatına renk katan bir şey olmaz” (K59); "Tedavinin ilaçlarla ya da deneylerle yapılması, kısacası doğal yolla iyileşme sağlanamadiğ için daha çok zarar görür” (K60); "AIDS hastalığl kan yoluyla bulaşan ve tedavisi zor ve meşakkatli bir hastalıktır. Kişiyi ölüme götürür. Hastalık ilerledikçe vücudun dışında gözle görünür bir bozulma meydana gelir" (K105); "AIDS zaman ilerledikçe ağırlaşır bir süre sonra en küçük bir hastalıkta ölüm kaçınılmaz olur" (K136); "AIDS insanların bir hatasından dolayı kendisine bulaşan, belki de o hatasını sürekli hatırlatan bir hastalıktır. Insanı toplumdan uzaklaştıran bir hastalıktır. Umutsuzluk, çaresizlik...", (K158); "AIDS kan yoluyla ve cinsellik aracılığıyla bayanlarda görülen bir hastalık çeşididir" (K192); "AIDS hastalarlyla temas etmemeliyiz" (K198); "Bulaşabilen iğrenç bir virüs" (K205); "AIDS virüsü kişileri birçok bakımdan sınırlayabilir. Vücut mikropla baş edemeyecek kadar bă̆ışılı̆̆l zaylf durumdadır. Ölümle sonuçlanabilir. Hastalı̆̆ın son hallerinde bireyde yaralar oluşabilir"'(K226); "...tedavi edilir bir hastalıktır" (K243); "AIDS pis bir hastalıktır" (K252); "AIDS'li hasta dikkatli olur korunursa yaşamına devam eder" (K262); "AIDS bulaşıcı bir hastalık olduğu için kişide korkunç karamsarlığa neden olur. Hayata isyan etmesine ve günlerinin kötü geçmesine neden olur. Bu konuda tedavide kolay ve ucuz olmadiğl için ölüm onlar için bir kurtuluş olur" (K274).
Model 1' de belirlendiği gibi, öğretmen adaylarının AIDS kavramıyla ilgili bilişsel yapılarına ait model çizim bulguları, yazım bulguları, alternatif kavramların tespit edildiği kategoriler ve en fazla tekrar edilen 10 kavram olmak üzere dört boyuttan oluşmaktadır.

\section{Tartışma, Sonuç ve Öneriler}

$\mathrm{Bu}$ araştırma öğretmen adaylarının çizme ve yazma tekniğinden yararlanılarak "AIDS" kavramı hakkındaki bilişsel kavramsal yapılarını belirlemek amacıyla hazırlanmıştır. Araştırmada veri toplamak amacıyla çizme ve yazma teknikleri birlikte kullanıldığından nitelikli, zengin ve birbirini hem destekler şekilde hem de detaylandırır şekilde kapsamlı veri elde edilmiştir. $\mathrm{Bu}$ kapsamda çizme-yazma tekniğinin birlikte kullanımıyla belirlenmiş olan veriler toplam 17 farklı kategori kapsamında dağılım göstermiştir. Bu kategoriler AIDS'in sonuçlart, AIDS'in taşlyıcılarl, AIDS'in bulaşma yolları, AIDS'in oluşma nedenleri, AIDS'in özellikleri, AIDS'in tedavisi, AIDS'in bulaşma nedenleri, AIDS'ten korunma yollarl, AIDS'in hastallk sürecinin özellikleri, AIDS'li hastanın algıları, AIDS'li hastaya bakış açısı, AIDS'e yönelik algllar, AIDS'in sembolleri, AIDS bulaşan ortamlar, AIDS'in görüldüğ̈̈ ülkeler, AIDS konusunda toplumu bilgilendirme ve AIDS'in basına yansımalart şeklinde sıralanmıştır. Diğer taraftan çizme tekniğiyle toplam 17 farklı kategori elde edilirken, yazma tekniğiyle toplam 16 farklı kategori elde edilmiş olup bu teknikle AIDS'in sembolleri kategorisi belirlenmemiştir. Bu sonuç öğretmen adaylarının AIDS'in sembollerini çizerek açıklamayı tercih ettiklerini ifade etmektedir. Sonuçlar öğretmen adaylarının AIDS kavramına ait bilgilerini hem çizimleriyle hem de yazımlarıyla bilgi birikimleri kapsamında çok yönlü olarak ifade ettiklerini göstermektedir. Belirlenen kategoriler; açık uçlu soru formu, anket ve görüşme yönteminin kullanıldı̆̆ 


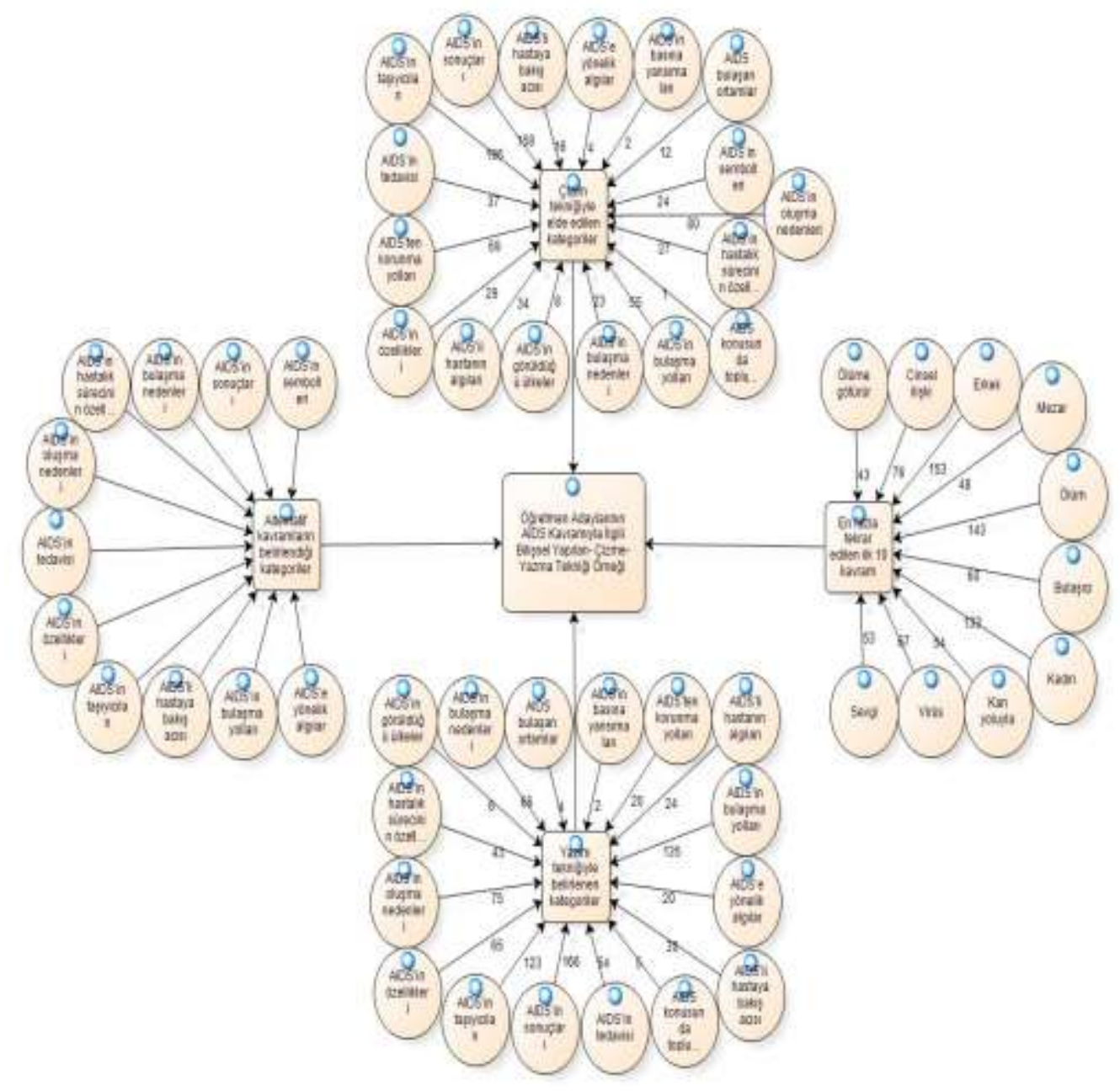

Model 1.Öğretmen Adaylarının AIDS Kavramıyla İlgili Çizme-Yazma Tekniğiyle Belirlenen Bilişsel Yapılarına Ait Oluşturulan Model

pek çok araştırmada belirlenen sonuçlarla benzerlik göstermektedir. Çünkü konuyla ilgili farklı katılımcı gruplarıyla yapılan araştırma sonuçlarında genel olarak katılımcıların bilgi düzeylerinin benzer kategorilerde yüksek çıktığı ifade edilmekte olup katılımcıların bilgi düzeylerinin en fazla AIDS'in sonuçlarl kategorisinde, AIDS'in bulaşma yollarl kategorisinde, AIDS'e yönelik algllar kategorisinde, AIDS'in tedavisi kategorisinde, AIDS'in taşlyıcıları kategorisinde, AIDS'ten korunmanın yolları kategorisinde, AIDS'li hastaya bakış açısı kategorisinde yüksek düzeyde ortaya çıktığı ifade edilmektedir (Altay ve diğerleri, 2006; Ekin, 2014; Kaya, Ak1llı ve Sezek, 2010; Kurt ve Y1lmaz, 2012; Reidpath ve Chan, 2005). Ancak bu araştırmada veri toplama araçlarından hem çizim hem de yazım tekniğinin özelliği gereği; katılımcıların AIDS kavramı konusunda düşüncelerini özgürce ifade etmeleri söz konusu olduğundan, diğer ölçme araçlarının kullanıldığı araştırmalara göre elde edilen verilerde AIDS konusundaki bilişsel yap1 kategorileri oldukça çeşitli şekilde elde edilmiştir. Elde edilen sonuçlar nitel araştırmalarda veri toplama araçlarında çeşitlemenin yapılmasıyla birbirini kontrol eder şekilde farklı ölçme tekniklerinin kullanılmasının nitelikli ve detaylı veri toplamakta tercih edilmesi gerektiğini ve önemli olduğunu bir kez daha ortaya koymuştur (Cinici, 2013).
Araştırma sonunda elde edilen kategoriler incelendiğinde; baskın olarak AIDS' in sonuçları kategorisinin tespit edilmiş olması farklı branşlarda eğitimlerine devam eden öğretmen adaylarının AIDS kavramıla ilgili zihinlerinde var olan bilişsel yapıları yönünden kabul edilebilir anlamlı bir sonuçtur. Çünkü bu sonuç öğretmen adaylarının somut olgulara, görülebilir sonuçlara ve AIDS'in sonuçlarının etkilerine odaklanarak AIDS hakkındaki bilişsel yapılarını ifade etmeye çalıştıklarını vurgulamaktadır. Her iki teknik kullanılarak bu kategoride en fazla Ölüm, Mezar, Üzüntülü haller, Hastalık ve Tabut kavramlarının ifade edildiği belirlenmiştir. $\mathrm{Bu}$ kavramlar AIDS kavramının ölüm şemasıyla ilişkili algılandığının göstergesi olarak değerlendirilebilir. Diğer taraftan tüm kategorilerde en fazla çizilen ve yazılan kavramların Erkek $(f=97)$ ve Kadın $(f=82)$ kavramları olduğu ortaya çıkmıştır. Bu sonuç AIDS'in öğretmen adayları tarafindan cinsel yolla bulaşan hastalıklar şeması içinde önemli bir yer aldığının vurgusu olarak kabul edilebilir.

Öğretmen adaylarının AIDS kavramıyla ilgili çizimleri 5 bilişsel seviye altında analiz edilmiştir. AIDS kavramıyla ilgili yapılmış olan çizimlerin temsili olmayan çizimler (201-\%67.91), alternatif kavramlar içeren çizimler (19\%6.42), kusmen doğru çizimler (6-\%2.03) ve kavramsal temsili-kapsamlı çizimler (15-\%5.07) olarak dağılım gösterdiği belirlenmiştir. Belirlenen bilişsel seviyeler öğretmen adaylarının yaklaşık olarak 3/4'lük bir oranının 
AIDS kavramıyla ilgili bilişsel yapılarını temsili olmayan çizimlerle ve günlük yaşamlarında farklı bilgi kaynaklarından elde ettikleri bilgilerle kendilerince oluşturdukları kavramlar kullanarak ifade ettiklerini göstermektedir. $\mathrm{Bu}$ sonuçlar öğretmen adaylarının AIDS kavramını kabul gören bilimsel boyutlarıyla yeterince ifade edemeden (veya bilmedikleri için olabilir) duygusal vurgusu yoğun olan basit ve bilimsel bilgilerle yeterince ilgisi olmayan, görselleştirerek ifade ettikleri çizimlerle ve zihinlerinde somutlaştırabildikleri içeriklere ait çizimlerle karikatürize edebildiklerini ifade etmektedir. Örneğin; AIDS hastalığına virüsün neden olduğu ifade edilirken hiçbir katılımcının akademik olarak doğru bir virüs şeklini çizemediği belirlenmiştir. Öğretmen adaylarının çizimlerinde AIDS'le ilgili bilişsel kavramsal yapılarını eksik ve çok fazla alternatif kavramlar içerir şekilde kişiselleştirdikleri çizimlerle yetersiz olarak ifade ettiklerini göstermektedir. $\mathrm{Bu}$ çizimlerinde AIDS'in sonuçlar kategorisinde Ölüm kavramına (63 çizim), AIDS'in taşıyıcıları kategorisinde taşıyıcılarından sadece bir grubu oluşturan Erkek (97 çizim) ve Kadın (82 çizim) kavramlarına ait çizimlerde yoğunlaştıkları belirlenmiştir. Diğer önemli bir sonuç ise, 65 (\%21.96) öğretmen adayının hiç çizim yapmadıkları belirlenmiştir. Avsar ve Soganci (2011) ve Baum, Owen ve Oreck (1997) öğrencilerin ders programlarında mutlaka görsel sanatlara ağırlık veren eğitimler alması ve buna uygun öğretim stratejileri kullanılması gerektiğini vurgulamaktadırlar. Böylece öğrenciler bilgileri daha kolay öğrenebilecek ve görsel zekalarının gelişmesinde etkili olacaktır. Cherney ve diğerleri (2006) çizimlerin öğrencilerin bilişsel yapılarının aynaları olduğunu ifade etmektedirler ki, bu araştırma sonuçlarına göre araştırmaya katılan farklı branşlardan öğretmen adaylarının AIDS kavramına ait bilişsel yapılarının yetersiz olduğunu söylemek mümkündür.

Öğretmen adaylarının AIDS kavramına ilişkin bilişsel yapılarının akademik bilgiden çok günlük konuşma dilinde kazanılmış bilgilerle yoğunluk kazandığını ifade etmek yanlış olmayacaktır. Elde edilen sonuçlar, geleceğin öğretmenleri olacak olan farklı branşlardan öğretmen adaylarının AIDS'le ilgili bilimsel bilişsel yapılarının daha amaçlı, nitelikli, farkındalığı yüksek etkili, doğru ve kabul edilebilir bilimsel bilgilerle geliştirilmeye ihtiyaç duyduğuna dikkat çekmektedir. Çünkü öğrenme sürecinde öğrenmeyi olumlu-olumsuz etkileyen en önemli faktörlerden biri konuyla ilgili zihnimizde var olan geçmiş tecrübelerimizle oluşmuş olan bilgi birikimidir. Bireyler bu mevcut bilgi birikimi içinde bilimsel gerçeklere karşılık gelmeyen fikirleri zihinlerinde anlamlandıramamaktadırlar. Öğrenilen kavramlar anlamlı öğrenilmemiş ve yapılandırılmamış ise öğrenme daha zorlaşmakta, hatalı kavram ve bilgilere yol açmaktadır. Araştırma sonuçları öğretmen adaylarının AIDS kavramıyla ilgili bir bütün olarak kapsamlı ve sistematik düşünemediklerini yansıtmaktadır. Bu noktada öğretmen adaylarının AIDS'in sebepleri, teşhis edilmesi, gelişim süreci, bulaşma yolları, sonuçları vb aşamaları belirtmeleri beklenilmekteyken, genelde sistematik olmayan bilgilerle bilişsel yapılarını ortaya koydukları belirlenmiştir.

Diğer taraftan araştırmada elde edilen önemli sonuçsal eksiklerden biri ise, araştırmaya katılan öğretmen adaylarından hiç birisi tarafından ifade edilmeyen en önemli bilgi eksikliği AIDS nasıl teşhis edilir?sorusuyla ilgili herhangi bir verinin elde edilememiş olmasıdır. Bu bir ölçü olarak kabul edilmeyebilir ancak, araştırmanın çalışma grubunun yaklaşık yarısının fen alanında eğitim alan öğretmen adaylarından oluşmuş olması böylesine önemli bir bilimsel bilgiyi ifade etmelerinin gerekliliğini vurgulamaktadır. Ancak öğretmen adaylarınca "AIDS hastalı̆̆ının kan testi ile tespit edildiğinin ve testin adının ELISA testi" olduğunu belirtmemeleri elde edilen sonuçlarda ve öğretmen adaylarının AIDS kavramıyla ilgili bilimsel bilişsel yapıları açısından oldukça önemli bir yetersizlik olarak değerlendirilebilir. Diğer taraftan araştırmaya katılan öğretmen adaylarından sadece birinin AIDS hastalığının tam adını [Edinilmiş ba $\breve{g}_{l s ̧ ı k l ı k}$ yetersizliği sendromu] şeklinde cevap kağıdına yazması oldukça değerli sonuçlardandır. Bu katılımcıların fen alanında eğitim alan katılıcılar olması önemli olup fen alanında eğitim alan diğer katılımcıların da bu bilimsel bilgiyi belirtmiş olmaları beklenilen sonuçlardan biriydi ve araştırmanın önemli sonuçlarından biri olabilirdi.

Belirlenen bu genel sonuçlar öğretmen adaylarının AIDS kavramı konusunda kabul gören bilimsel bilgilerinin yeterli olmadığının göstergesi olarak kabul edilebilecek sonuçlardan sadece birkaçıdır. Ancak yapılan araştırmalarda da toplumun farklı kesiminden katılımcıların AIDS kavramıyla ilgili çok fazla alternatif kavramlara sahip olduklarını ve bilimsel bilgilerinin yeterli olmadığı ifade edilmektedir (Gao ve diğerleri, 2012; Letamo, 2007; Munthali ve diğerleri, 2004).Yapılan araştırma sonuçlarıyla bu araştırma sonuçları benzerlik göstermektedir.

Sonuç olarak, araştırmada elde edilen veriler farklı alanlarda eğitim gören öğretmen adaylarının AIDS kavramıyla ilgili bilimsel bilişsel yapılarının yeterli olmadığını ve kesinlikle ciddi bir eğitim programıyla bilinçli olarak geliştirilmesine ihtiyaç duyulduğunu göstermektedir. İlk ortaya çıktığı yıllardan günümüze kadar AIDS'in dünyadaki her bireyi tehdit eden ve bulaşma riskinin yüksek olduğu bir hastalık olduğu göz önüne alınarak eğitim sürecinin amaç temelli olarak dikkatlice planlanması gerekmektedir. Ancak araştırmalarda AIDS konusuna Türkiye'de eğitim sisteminde verilmesi gereken önemin verilmediği vurgulanmaktadır (Çok, 1997). Bütün dünyada gün geçtikçe daha tehlikeli boyutlara ulaşarak milyonlarca insanı etkilemeye devam eden HIV/AIDS konusunda maalesef ki Türkiye'de de toplumun \% 77.3'ünün bilgisiz olduğu ifade edilmekte (https://indigodergisi.com/2017/11/hiv-aids-arastirmasi)

olup bu araştırmaya katılan öğretmen adaylarının da yeterli bilimsel bilgiye sahip olmadıkları belirlenmiştir. AIDS'in gün geçtikçe kontrol edilebilmesi için çok fazla çaba gösterilmesi gereken bir hastalık olması sebebiyle birçok ülkede farklı eğitim kademelerinde çok küçük yaşlardan itibaren öğrencilerin bilinçlendirilmesi zorunludur. Özellikle fen eğitimi kapsamında AIDS eğitiminin verilmesi sağlanmaktadır (Çok, 1997; Gallanta ve MatickaTyndaleb, 2004; Kiragu, 2007; Kyrychenko ve diğerleri, 2006; Slusher ve Anderson, 1996). Farklı kitalardaki pek çok ülkede AIDS eğitimi ilköğretimden itibaren farklı öğretim kademesinde yer almaktayken Türkiye'de gelecek kuşakların öğretmenleri olmaya hazırlanan farklı branş öğretmen adaylarının AIDS kavramı konusundaki eğitimlerine önem verilmelidir. Türkiye'de de AIDS konusuna eğitim programlarında gerekli ciddiyetin 
gösterilerek yer verilmesi gerekliliği bu araştırma sonuçlarıyla bir kez daha ortaya çıkmıştır. Özellikle bu araştırma sonuçlarından AIDS konusunda toplumu bilgilendirme ve AIDS'in basina yansimalart kategorilerinin en son siralarda belirlenmiş olması bu açıdan oldukça dikkat çekicidir. Bu sonuç Türkiye'de AIDS hastalığına gerekli dikkatin çekilmediği yönünde algilanabilir.

Araştırmada belirlenmiş olan sonuçlar kapsamında konuyla ilgili aşağıdaki öneriler sunulabilir;

1.Bu araştırma nitel araștırma modeli kapsamında kullanılan farklı ölçme araçlarıyla desteklenerek (kelime testleri, görüşme, kişisel yazma örneklerinin kullanılması gibi) yapılabilir.

2. Öğretmen adaylarının alternatif kavramlarının ve eksik bilgilerinin giderilmesi yönünde farklı öğretim yaklaşımlarının etkililiğini belirlemeye yönelik deneysel desende çalışmalar düzenlenebilir.

3.Farklı öğretim kademesinde yer alan farklı dersler kapsamında dersin içeriğine uygun olarak öğretim programlarında AIDS konusunda aydınlatıcı bilgileri öğrenmelerine imkanlar sağlanabileceği gibi özellikle öğrencilerin sağlık konusunda eğitim alabilecekleri sağlık eğitimi dersi ders programlarına dahil edilebilir. Bu ders kapsamında AIDS başta olmak üzere pek çok hastalıklar ve sağlıklı yaşam konusunda öğrencilere bilgi verilebilir.

4. Eğitim fakülteleri dahil olmak üzere tüm öğretim kademelerinde sağlık eğitimi dersi zorunlu ders olarak okutulabilir.

\section{Kaynakça}

Ainsworth, S., Prain, V., \& Tytler, R. (2011).Drawing to learn in science.Science Education,333, 1096-1097.

Altay, B., Gönener, H.D., Aygut, G., \& Kılıç, A. (2006). Öğrenci yurdunda kalan üniversite öğrencilerinin AIDS konusunda bilgi tutum ve davranışlarının değerlendirilmesi. Türk HIV/ AIDS dergisi,9 (4), 116124.

Artan, M.O.,\& Güleser, G.H. (2006). Sağlık Okulu Öğrencilerinin HIV/AIDS, hepatit Bvirüsü ve hepatit C virüsü konusundaki bilgi düzeylerinin değerlendirilmesi.Erciyes Tip Dergisi, 28(3), 125-133.

Avsar, P., \& Soganci, I.O. (2011). Student approaches towards visual arts lesson which is taught by classroom teacher: Case of Seydişehir / Konya region. Elementary Education Online, 10 (1), 348-363.

Backett-Milburn, K.,\& McKie, L. (1999). A critical appraisal of the draw and write technique.Health Education Research Theory \& Practice, 14(3), 387-398.

Bartoszeck, A.B., Machado, D.Z., \& Amann-Gainotti, M. (2008). Representations of internal body image: A study of preadolescents and adolescent students in Araucaria, Paraná, Brazil. Ciências \& Cognição, 13 (2), 139-159.

Baum, S.M., Owen, S.V., \& Oreck, B.A. (1997). Using art processes to enhance academic self-regulation. paper presented at arts connection national symposium on learning and the arts: New strategies for promoting student success, New York, February 22, 1997.

Beydağ, K.D.T. (2007). Sağlık yüksekokulunda öğrenim gören bir grup üniversite öğrencisinin HIV/AIDS konusundaki bilgi düzeyleri. TSK Коrиуиси Hekimlik Bülteni, 6 (1), 59-68.

Bilgin, N. (2006). Content analysis techniques and case studies in social sciences. Ankara: Siyasal Publication.

Bogdan, R.C.,\& Biklen, S.K. (2007). Qualitative research for education(5th ed). Boston: Pearson Education, Inc.

Borthwick, A. (2011). Children's perceptions and attitudes towards, their mathematics lessons. In C. Smith (Ed.), British society for research into learning mathematics, 31, 37-42.

Brotman, J.S., Mensah, F.M., \& Lesko, N. (2010). Urban high school students' learning about HIV/AIDS in different contexts. Science Education,95 (1), 87-120.

Byrne, J. (2011). Models of micro-organisms: Children's knowledge and understanding of micro-organisms from 7 to 14 years old. International Journal of Science Education,33 (14), 1927-1961.

Cetin, G., Ozarslan, M., Isik, E., \& Eser, H. (2013). students' views about health concept by drawing and writing technique. Energy Education Science and Technology, Part B, 5 (1), 597-606.

Cherney, I.D., Seiwert, C.S., Dickey, T. M., \& Flichtbeil, C.D. (2006). Children's drawings: A mirror to their minds. Educational Psychology, 26(1), 127-142.

Chi, M.T., Slotta, J.D., \& Leeuw, N. (1994). From things to processes: A theory of conceptual change for learning science concepts.Learning and Instruction, 4, 27-43.

Christensen, P.,\& James, A. (2000). Research with children. London: Falmer Press.

Cinici, A. (2013). From caterpillar to butterfly: A window for looking into students' ideas about life cycle and life forms of insects. Journal of Biological Education, DOI:10.1080/00219266.2013.773361.

Cohen, L.,\& Manion, L. (1997). Research methods in education. London: Routledge.

Cohen, L., Manion, L., \& Morrison, K. (2007). Research methods in education. New York, NY: Routledge.

Çekin, Y., Özdemir, A., Şenol, Y.Y., \& Çekin, A.H. (2013). Üçüncü basamak bir hastanede sağlık çalışanlarının HIV konusunda bilgi ve davranış biçimlerinin araştırılması. Journal of Clinical and Analytical Medicine,4(4), 291-296.

Çok, F. (1997). HIV/AIDS üzerine. Yaşadıkça Ĕ̆itim Dergisi, 51, 25-26.

Daymon, C.,\& Holloway, I. (2003). Qualitative research methods in public relations and marketing communications. London: Rout ledge.

Doran, R.L. (1972). Misconception of selected science concepts held by elementary school students. Journal of Research in Science Teaching,9 (2), 127-137 
Driver, R. (1989). Students' conceptions and the learning of science. International Journal of Science Education, 11, 481-490.

Driver, R. \& Easley, J. (1978). Pupils and paradigms: A review of literature related to concept development in adolescent science students. Studies in Science Education, 5, 61-84.

Ekin, G.U. (2014). Lise öğrencilerinin HIV/AIDS ile ilgili bilgi düzeyi ve tutumlarının değerlendirilmesi. Bakırköy Tip Dergisi, 10(1), 24-26.

Ergazaki, M., Saltapida, K., \& Zogza, V. (2010). From young children's ideas about germs to ideas shaping a learning environment. Research in Science Education,40, 699-715.

Ergör, G.,\& Serdar, B. (1998). HIV/AIDS epidemiyolojisi ve korunma. S. Ünal (Edt.) Güncel bilgiler ışı̆̆ında HIV/AIDS, (ss. 7-20). Ankara: Bilimsel Tıp Yayınevi.

Esen, A. (1993). Toplumun AIDS'e ilişkin bilgi düzeyinin ve eğitim gereksiniminin incelenmesi.Ege Üniversitesi Hemşirelik Yüksek Okulu Dergisi, 9 (2), 9-19.

Eskiocak, M.,\& Saltık, A. (2002). Cinsel yolla bulaşan hastalıklar ve HIV/AIDS epidemiyoloji ve korunma ders notları.Edirne: Trakya Üniversitesi Tıp Fakültesi Halk Sağlığı Anabilim Dalı.

Franco, C., Lins, H., Colinvaux, D., Krapas, S., Queiroz, G., \& Alves, F. (1999).From scientist's and inventors' minds to some scientific and technological products: relationships among theories, models, mental models and conceptions.International Journal Science Education, 21(3), 277-281.

Gallanta, M.,\& Maticka-Tyndaleb, E. (2004). School-based HIV prevention programmer for African youth. Social Science \& Medicine,58, 1337-1351.

Gan'Czak, M., Barss, P., Alfaresib, F., Almazroueic, S., Muraddadc, M., \& Al-Maskari, F. (2007). Break the silence: HIV/AIDS knowledge, attitudes, and educational needs among Arab university students in United Arab Emirates. Journal of Adolescent Health, 40 (6), 572-578.

Gao, X., Wu, Y., Zhang, Y., Zhang, N., Tang, J., Qiu, J., Xiaofang, L., \& Du, Y. (2012). Effectiveness of schoolbased education on HIV/AIDS knowledge, attitude, and behavior among secondary school students in Wuhan, China. PLoS ONE,7(9), e44881.

Garland, H.D. (2005). Evidence of witnessed community violence in children's drawings. Dissertation Abstracts International: Section B: The Sciences and Engineering, 65(12-B), 6650.

Gilbert, J.K., Boulter, C., \& Rutherford, M. (1998a). Models in explanations, part 1, Horses for courses? International Journal of Science Education, 20, 83-97.

Gilbert, J. K., Boulter, C., \& Rutherford, M. (1998b). Models in explanations, part 2, whose voice? whose ears?International Journal of Science Education,20, 187-203.

Given, L.M.(2008).The sage encyclopedia of qualitative research methods. Sage:Thousand Oaks, CA.
Gonzalez, F. M. (1997). Diagnosis of spanish primary school students' common alternative science concepts.School Science and Mathematics, 97(2), 6874.

Glick, R.A. (1193). Law, ethics\& HIV.UNDP, New Delhi.

González-Rivera, M. (2007). Children's attitudes toward people with AIDS in Puerto Rico: Exploring stigma through drawings and stories.Qualitative Health Research, 17(2), 250-263.

Greca, I.M.,\& Moreira, M.A. (2000). Mental models, conceptual models, and modeling.International Journal of Science Education, 22(1), 1-11.

Green, C.J. (2007). HIV infection and AIDS, In: F.D. Monahan, J.K. Sands, M. Neighbors, J.F. Marek, C.J. Green, (Eds.), Phipps' medical-surgical nursing: Health and illness perspectives mosby. St. Louis, Missouri, USA.

Hill, C.E., Thompson, B.J., \& Williams, E.N. (1997). A guide to conducting consensual qualitative research. The Counseling Psychologist,25, 517-572.

Hruschka, D.J., Schwartz, D., St.John, D.C., PiconeDecaro, E., Jenkins, R.A., \& Carey, J.W. (2004). Reliability in coding open-ended data: Lessons learned from HIV behavioral research. Field Methods,16(3), 307-331.

http://www.AIDSbelirtileri.com/AIDS.html

İçli, G.,\& Yalçın, A.N. (2002). Eğitim ve fen-edebiyat fakültesi ögrrencilerinin AIDS hakkındaki bilgi düzeyleri. HIV/ AIDS, 5, 25-29.

İnci, A. (2014).Knowledge level and attitude of health care workers about HIV/AIDS. Journal of Clinical and Analytical Medicine,5(5), 394-396.

Kadıoğlu, D. (2002). Güvenli Cinsel Yaşam. S. Ünal (Edt.), Sosyal bilimler alanında ĕgitim gören üniversite gençliğinde HIV/AIDS'in önlenmesi akran ĕgitimi, (ss.123-131). Ankara: HATAM, UNICEF ve AIDS Savaşım Derneği.

Kalvaitis, D.,\& Monhardt, R.M. (2012). The architecture of children's relationships with nature: A phenomenographic investigation seen through drawings and written narratives of elementary students. Environmental Education Research,18 (2), 209-227.

Kaya, E., Akıllı, M., \& Sezek, F. (2010). Lise öğrencilerinin HIV/AIDS konusundaki bilgi düzeylerinin farklı değişkenler açısından incelenmesi. Pamukkale Üniversitesi Eğitim Fakültesi Dergisi,27, 139-145.

Kiragu, S.W. (2007). Exploring sexuality education and the burdened teacher: A participatory approach in a rural primary school in Kenya. Pastoral Care in Education, 25(3), 5-15.

Kıyan, M., Cengiz, L.,\&Cengiz, T. (1993). Human Immune Deficiency Virus (HIV)'un bulaşma yolları ve AIDS'in risk gruplar1. Ondokuz Mayls Üniversitesi Tip Dergisi, 10(1-2), 57-64. 
Knight, S.L., Nolan, J., Lloyd, G., Arbaugh, F., Edmondson, J., \& Whitney, A. (2013). Quality teacher education research: How do we know it when we see it?Journal of Teacher Education,64(2), 114-116.

Korkmaz, H. (2001). Hizmet öncesi öğretmenlerin AIDS Eğitimine yönelik bilgi ihtiyaçlarının ve bilgi kaynaklarının incelenmesi.Hacettepe Üniversitesi Ĕ̈itim Fakültesi Dergisi, 21, 75-80.

Kökdemir, H. (2001). Turkish university students' blame attributions and attitudes toward people with AIDS. Yayımlanmamış Yüksek Lisans Tezi. Ankara: Orta Doğu Teknik Üniversitesi.

Köse, Ş., Mandıracı, A., Kaptan, F., Özbel, Y., \& Mermut, G. (2012). Sağlık çalışanlarının HIV/AIDS ile ilgili konularda eğitildikten sonra artan bilgi ve tutumlari: Türkiye'de kentsel alanda yapılmış bir çalışma. Türkiye Klinikleri Journal of Medical Sciences,32(1), 94-103.

Krahnke, H.(1992). AIDS'ten Böyle Korunurum 300 Soru 300 Yantt. İstanbul: AIDS Savaşım Derneği.

Kyrychenko, P., Kohler, C., \& Sathiakumar, N. (2006) Evaluation of a school-based HIV/AIDS educational intervention in Ukraine. Journal of AdolescentHealth,39, 900-907.

Kurt, A.S.,\& Yılmaz, S.D. (2012). Sağlık yüksekokulu öğrencilerinin HIV/AIDS hakkındaki bilgi düzeyleri ve bilgi kaynakları.Hemşirelikte Ĕgitim ve Araştırma Dergisi,9(3), 47-52.

Leblebici, D.N.,\& Kılıç, M. (2004). İçerik analizi.Ankara: Hacettepe Üniversitesi Yayınları.

Letamo, G. (2007). Misconceptions about HIV prevention and transmission in botswana.African Journal of AIDS Research, 6(2), 193-198

Lichtman, M. (2010). Qualitative research in education. Los Angeles: Sage.

Lin, T.C., Lin, T.J., \& Tsai, C.C. (2014). Research trends in science education from 2008 to 2012: A systematic content analysis of publications in selected journals. International Journal of Science Education, 36(8), 1346-1372.

Mcmillan, J.H. (2000). Educational research: Fundamentals for the consumer. New York: Longman.

Mike, M.,\& Treagust, D.F. (1998). A pencil and paper instrument to diagnose students' conceptions of breathing, gas exchange and respiration.Australian Science Teachers Journal,44(2), 55-60.

Miles, M.B.,\& Huberman, A.M. (1994). Qualitative data analysis. Thousand Oaks, CA: Sage.

Munthali, A.C., Chimbiri, A., \& Zulu, E. (2004) Adolescent sexual and reproductive health in Malawi: A synthesis of research evidence. Occasional Report No. 14, The Alan Guttmacher Institute, New York.

Mutonyi, H., Nashon, S., \& Nielsen, W.S. (2010). Perceptual influence of Ugandan biology students' understanding ofHIV/AIDS. Research in Science Education, 40, 573-588.
Novak, J.D. (2002). Meaningful learning: The essential factor for conceptual change in limited or inappropriate propositional hierarchies leading to empowerment of learners.Science Education,86(4), 548-571.

Nwokocha, A.R.C.,\& Nwakoby, B.A.N. (2002). Knowledge, attitude, and behavior of secondary (high) school students concerning HIV/AIDS in Enugu, Nigeria, in the Year 2000. Journal of Pediatric and Adolescent Gynecology, 15, 93-96.

Nyachwayaa, J. M., Mohameda, A-R., Roehriga, G. H. Woodb, N. B., Kernc, A. L., \& Schneiderd, J.L. (2011). The development of an open-ended drawing tool: an alternative diagnostic tool for assessing students' understanding of the particulate nature of matter. Chemistry Education Research and Practice,12 (2), 121-132.

Özcebe, H., Akın, L., \& Aslan, D. (2004). A peer education example on HIV/AIDS at a high school in Ankara. The Turkish Journal of Pediatrics, 45,54-59.

Özdemir, M., Feyzioğlu, B., Doğan, M., Baykan, M., \&Baysal, B. (2006). Üniversite öğrencilerinin HIV/AIDS hakkındaki bilgi düzeyi ve tutumlarının değerlendirilmesi. Türk HIV/ AIDS dergisi,9 (1), 10-16.

Paivo, A. (1990). Mental representations: A dual-coding approach. New York: Oxford University Press.

Patton, M.Q. (1990). Qualitative Evaluation and Research Methods. USA: Sage.

Patrick, P.G.,\& Tunnicliffe, S.D. (2010). Science teachers' drawings of what is inside the human body. Journal of Biological Education, 44 (2), 81-87.

Pekșen, Y., Dabak, Ş., Leblebicioğlu, H., \& Günaydın, M. (1994). Gençlerin eğitim öncesi ve sonras1 AIDS konusundaki bilgi düzeyleri. Yeni Tıp Dergisi, 11-13.

Punch, K.F. (2005). Introduction to social researchquantitative \& qualitative approaches.London: Sage.

Ratcliff, D. (1995). Validity and reliability in qualitative research.http://qualitativeresearch.ratcliffs/Validity.pdf

Reidpath, D.D.,\& Chan, K.Y. (2005) A method for the quantitative analysis of the layering of HIV-related stigma. AIDS Care: Psychological and Socio-medical Aspects of AIDS/HIV, 17 (4), 425-432.

Reiss, M.J.,\& Tunnicliffe, S.D. (2001). Students' understandings of human organs and organ systems. Research in Science Education,31, 383-399.

Reiss, M.J., Tunnicliffe, S.D., Andersen, A.M., Bartoszeck, A., Carvalho, G.S., Chen, S.-Y., et al. (2002). An international study of young peoples' drawings of what is inside themselves.Journal of Biological Education, 36 (2), 58-64.

Rennie, L.J.,\& Jarvis, T. (1995). Children's choice of drawings to communicate their ideas about technology. Research in Science Education, 25(3), 239-252.

Roberts, P.,\& Priest, H. (2006). Reliability and validity in research. Nursing Standard,20, 41-45. 
Rotheram-Borus, M.J., O’keefe, Z., Kracker, R., \& Foo, H. (2000). Prevention of HIV among adolescents. Prevention Science, 1, 15-30.

Shepardson, D. P., Wee, B., Priddy, M., \& Harbor, J. (2007). Students' mental models of the environment. Journal of Research in Science Teaching,44 (2), 327348.

Slusher, M.P.,\& Anderson, C.A. (1996) Using causal persuasive arguments to change beliefs and teach new information: the mediating role of explanation availability and evaluation bias in the acceptance of knowledge.Journal of Educational Psychology,88, 110122.

Smith, E.L., Blakeslee, T.D., \& Anderson, C.W. (1993). Teaching strategies associated with conceptual change learning in science. Journal of Research in Science Teaching,30(2), 111-126.

Stemler, S. (2001). An overview of content analysis. Practical assessment.Research\&Evaluation,7(17), 1-8.

St. Lawrence, J.S., Crosby, R.A., Brasfield T.L., \& O'bannon, R.E (2002). Reducing STD and HIV risk behavior of substance-dependent adolescents a randomized controlled trial. Journal of Consulting and Clinical Psychology, 70 (4), 1010-1021.

Stine, G.J. (1996). Acquired immune deficiency syndrome. New Jersey: Prentice Hall.

UNAIDS/WHO. (2012). AIDS epidemic update.http://www.unAIDS.org/en/media/unAIDS/conte ntassets/documents/epidemiology/2012/gr2012/2012112 0_UNUNAI_Global_Report_2012_en.pdf],Retrieved on September 14, 2013.
Uzunkaya, A.,\& Özgür, S. (2011). Effects of an instruction based on dominant intelligence on overcoming misconceptions.Hacettepe University Journal of Education,41, 461-472.

Tümer, A.,\& Ünal, S. (2003). HIV/AIDS epidemolojisinde gelişmeler ve korunma. Sürekli Tip Eğitim Dergisi, 12 (1), 15-18.

Verma, G.K.,\& Mallick, K. (1999). Researching education: Perspectives and techniques. London: Falmer Press.

Vosniadou, S.,\& Brewer, W. (1994a). Mental models of the day/night cycle.Cognitive Science, 18, 123-183.

Vosniadou, S.,\& Brewer, W. (1994b). Capturing and modeling the process of conceptual change.Learning and Instruction, 4, 45-69.

WHO (1992). World health statistics annual 1991. WHO, Geneva.

Wiersma, W.,\& Jurs, S.G. (2005). Research methods in education: an introduction. Boston: Ally and Bacon.

Wimmer, R.D.,\& Dominick, J.R. (2000). Mass media research: An introduction. Belmont: Wadsworth Publishing Company.

Yıldırım, A.,\& Şimşek, H. (2016). Sosyal bilimlerde nitel araştırma yöntemleri (10.Baskı).Ankara: Seçkin Yayıncilik.

Yin, R. (2003). Case study research: Design and methods. Thousand Oaks: Sage. 